ENTREPRENEURSHIP AND SUSTAINABILITY ISSUES

ISSN 2345-0282 (online) http://jssidoi.org/jesi/

2019 Volume 6 Number 3 (March)

http://doi.org/10.9770/jesi.2019.6.3(11)
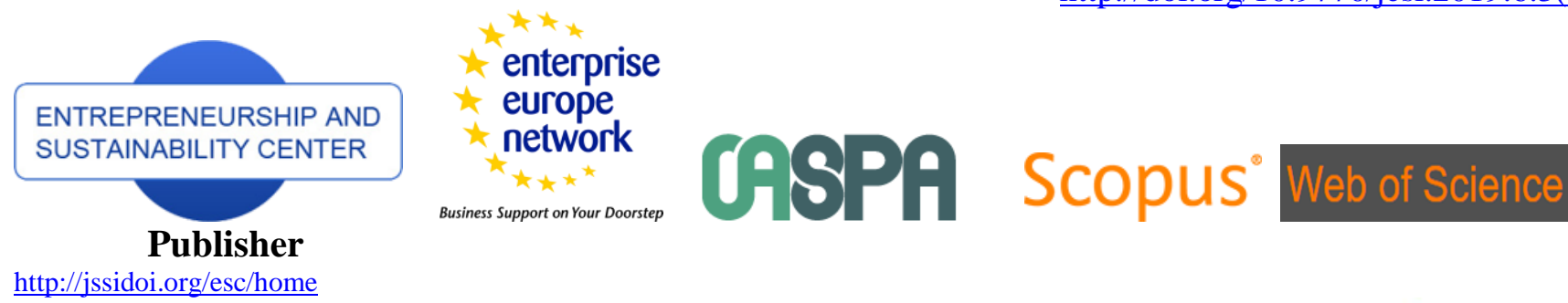

http://jssidoi.org/esc/home

\title{
LABOR MARKET SECURITY IN THE LIGHT OF EXTERNAL LABOR MIGRATION: NEW THEORETICAL FINDINGS
}

\author{
Anna Lialina \\ Center for Modeling of Social and Economic Development of the region, \\ Immanuel Kant Baltic Federal University, Gorkogo str., 23, Kaliningrad, Russia \\ E-mail: anuta-mazova@mail.ru
}

Received 14 July 2018; accepted 25 November 2018; published 30 March 2019

\begin{abstract}
Conceptualizing the consequences of external labor migration for the development of the labor market of the receiving territory is an extremely important and relevant area for studying migration effects. It develops in parallel with the intensification of labor migration processes in the world, the expansion of the methodological tools and the information base of research. The subject of this paper is the impact of external labor migration on the labor market security. The study aims to substantiate the relevance of a new interdisciplinary approach to the study of the effects of labor migration on the host labor market, namely the analysis of risks and threats, labor market security factors in the sphere of external labor migration. The study is carried out using methods of systematization and classification, general dialectical methods. The analysis suggests that labor market security in the sphere of external labor migration can act as an independent area of research for migratory consequences in labor markets. It relies upon the findings of national security studies and the established directions for studying the impact of external labor migration on the labor market of the recipient territory.
\end{abstract}

Keywords: labor market sustainability; labor market security; international labor migration; migration effects; migration consequences; labor market; migrant workers; path dependence

Reference to this paper should be made as follows: Lialina, A. 2019. Labor market security in the light of external labor migration: new theoretical findings, Entrepreneurship and Sustainability Issues 6(3): 1205-1225. http://doi.org/10.9770/jesi.2019.6.3(11)

JEL Classifications: J61, F52, R23

\section{Introduction}

Global changes that have occurred in the last quarter of a century in the political, economic, social, and technological life of modern societies have given impetus to the unprecedented migration mobility of the population. In 2017 nearly 258 million people worldwide were involved in the international migration (i.e. people living outside their birthplace), or 3.4\% of the total population of the Earth - this is the highest value in the entire history of the observations (International Migration Report 2017, 2017). Over the past 25 years, the number of international migrants has increased by more than 91 million people, or $60 \%$. Despite the colossal growth and

\footnotetext{
* The research was carried out at the expense of a grant from the Russian Science Foundation (project № 18-17-00112 «Ensuring economic security of Russia's western border regions in the conditions of geopolitical turbulence».
} 


\section{ENTREPRENEURSHIP AND SUSTAINABILITY ISSUES}

ISSN 2345-0282 (online) http://jssidoi.org/jesi/

2019 Volume 6 Number 3 (March)

http://doi.org/10.9770/jesi.2019.6.3(11)

intensification of the processes of forced migration, especially in North Africa and the Middle East, about $72 \%$ of all international migrants now make people aged 20-64 years, which allow us to speak about the high labor activity and the potential of the latter.

Against the backdrop of a change in the pattern of migration mobility of the population, it is generally necessary to single out the flows of international labor migration, which are mainly influenced by the globalization of the world economy that abolishes barriers to the transfer of capital, information, and technology. The internationalization of the world economy means the transition from closed or semi-closed labor markets to the world market, which is formed and exists only through labor migration (Shchipanova, 2013). According to the latest statistical estimates of the International Labor Organization, the number of migrant workers (i.e. persons working or seeking employment in their country of residence) in the world in 2013 totaled 150.3 million people, or $64.8 \%$ of all international migrants, that is about $4.4 \%$ of the total employed population (International Labour Office, 2015).

Clearly, these processes have a significant impact on the development of migrant-receiving territories. Over the past 60-70 years scientists around the world have been anxious about the power of this influence and the changes happening to the ecosystems of the host society (Lyalina, 2016). A special niche in the number of modern studies is occupied by those of them, focusing on the subject of labor market. It should be noted that today the scientific community is unanimous that any type of migration of the population influences the formation of the labor supply and the development of the host labor market; however, most of the relevant studies are aimed at studying the consequences of labor migration of the population. This is due to the economic nature of such migration, i.e. the orientation of migrants to participate in the labor market, on the one hand, and, accordingly, the need to regulate these processes with a view to the balanced and sustainable development of the labor market by the host state, on the other.

Despite the huge accumulated experience in studying these issues, the identified consequences are not systematized in the modeling of the processes occurring in the labor markets under the impact of labor migration. The economic and sociological approaches prevail in the studies, while the geography is given a secondary role. As a rule, scientists resort to purely geographic methods of research while studying the spatial features revealed and described using economic and sociological methods. Another obvious shortcoming of the existing studies is insufficient knowledge on the issues of ensuring the security of the labor market, the risks and threats, which follow the attraction and use of foreign labor. The reason for this is the lack of an established understanding of the term security of the labor market both nationally and internationally. The study is determined by the need to systematize and classify available scientific approaches to studying the impact of labor migration on the development of the labor market, generalization of the migrations consequences to labor market development in terms of the labor market security. The study aims to substantiate the new interdisciplinary scientific approach in investigating the effects of external labor migration in terms of creating risks and threats, while taking into account their geographical specifics. To do this, it is necessary to initially determine the security of the labor market in the system of national or regional security components. The study is carried out using methods of systematization and classification, general dialectical methods.

\section{Approaches to studying the effects of labor migration on labor market development}

The problem of assessing the impact of migration, and especially its labor component, on the development of the labor market, has been of great interest for representatives of various scientific schools: economics, sociology and ethnoculture, geography, political science, law and others. Determination of the relevant scientific publications on the topic has led to a classification of the main research areas of the study of the impact of external labor migration on the labor market of the host territory featuring 23 directions (Figure 1). The classification is based on the principle of correlating the research areas with the scientific approach, which is determined by the goals and 
objectives used by the given research method. Within the framework of the classification it is proposed to formulate a new research area entitled "labor market security in the sphere of external labor migration", which can take its position at the intersection of existing areas based on the accumulated experience. This research area is interdisciplinary and includes analysis and assessment of all possible migration consequences in terms of risks and threats, factors of the labor market security. It should be noted that the classification proposed has some limitations as it is not all-embracing (some individual aspects might be left aside) and is generalized, since a particular research area can be simultaneously considered in the framework of different approaches. The main attention is paid to economic, sociological and geographical studies.

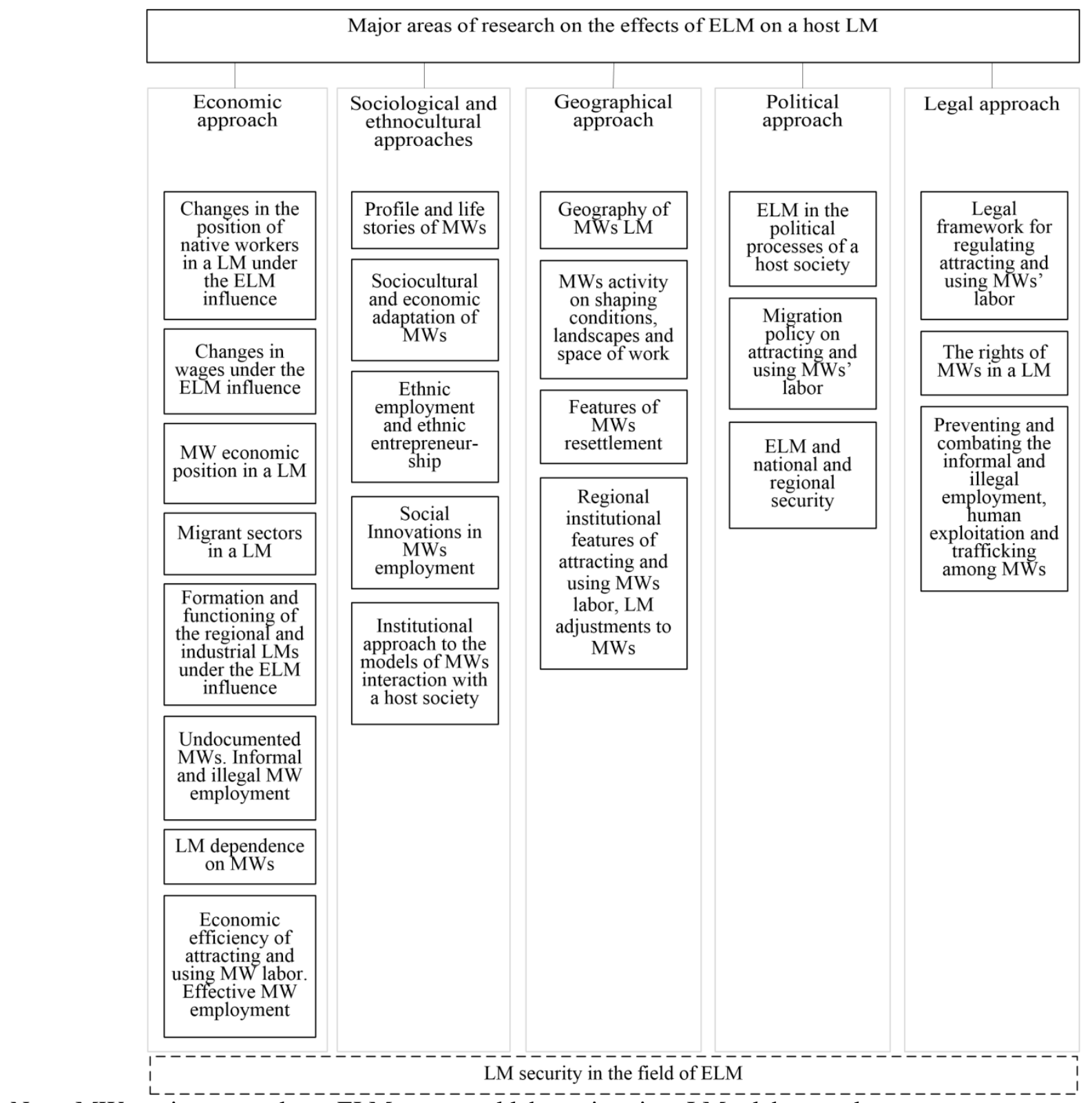

Note: MW - migrant workers; ELM - external labor migration; LM - labor market

Fig. 1. A classification of major areas of research on the effect of external labor migration on the host labor market. Source: Own elaboration. 


\section{ENTREPRENEURSHIP AND SUSTAINABILITY ISSUES}

ISSN 2345-0282 (online) http://jssidoi.org/jesi/

2019 Volume 6 Number 3 (March)

http://doi.org/10.9770/jesi.2019.6.3(11)

In the 1960s theoretical economists pioneered research on the negative consequences of labor migration on the development of the host labor market, which is reflected in the classical and neoclassical models of the economic growth of Solow-Swan (1956) and Ramsey (1928) were the migration is seen as a factor in the growth of the labor force. The main idea of the first publications on the topic was that the international movement of the labor force, as one of the factors of production, affects the rate of economic growth. In general, the inclusion of migration component as the main source of labor force in the theoretical models of economic growth of SolouSwan and Ramsay contradicted the estimates of public authorities and demonstrated the negative impact of migration processes on economic growth including on the capital-labor ratio of the economy and labor productivity (Barro and Sala-i-Martin, 2003). Early studies suggest that the net outflow of the population is found to contribute to economic growth, a net inflow slows it due to an increase in supply in the labor market and a decrease in the efficiency of the use of fixed capital. However, later empirical studies of Barro \& Sala-i-Martin (Barro and Sala-i-Martin, 2003) and Lifshits (Lifshits, 2013) proved otherwise. In particular, Livshits (Lifshits, 2013) came to the conclusion that the long-term impact of migration is usually positive or insignificant. The only exception is countries with a high level of natural reproduction of labor resources, where the negative impact of migration on economic development is possible.

Later, as the methodological tools and the database of input data were expanded, scientists proposed a number of research areas in this subject: the study of the consequences of competition among workers from the local and newly arrived population (taking into account their professional heterogeneity) for the position of local workers in the labor market and their remuneration (Borjas, 2003; Angrist and Kugler, 2001; Kugler and Yuksel, 2008; Škuflić et al., 2018); economic situation of the legalized (Chiswick \& Hurst, 1998; Borjas, 1987) and un legalized (Boswell and Straubhaar, 2004) migrant workers in the labor market; evaluation of the economic efficiency of attracting and using labor of migrant workers (Ekberg, 2004); analysis of the 'ethnic' specialization and segmentation of the labor market of the host territory (Piore, 1980; Sassen, 1988).

The latter is closely associated to the research on the dependence of individual industries and the entire economy on migrant labor (Martin, 2010; Castles and Kosack, 1973). Simultaneously, as the experimental studies disproved the assumptions of theoretical research (e.g., the effect of migration on wage changes was found to be insignificant), the view of scientists was addressed to the topic of "absorption" of migrants by the host labor market (Braun and Weber, 2016).

Russian school of economics largely moved in parallel with the research of global research. However, their distinctive feature is a broader, more ambitious approach to the subject under study. In the Soviet period, research was developed on the organization of labor migration in the context of the planned economy of the USSR (Topilin 1975), the definition of the economic function of migration in the labor market (Khomra, 1979), the impact of migration on the formation and functioning of the Russian model of the labor market (Topilin and Parfenceva, 2006). Contemporary research of Russian scientists in this field focuses on the identification of discrimination of foreign workers in the labor market and an analysis of their economic activity (Vakulenko and Leukhin, 2016; Lokshin and Chernina, 2013), the study of the forms, extent and consequences of illegal employment among migrants (Ryazantsev, 2016b; Ioncev and Ivakhnyuk, 2012), the analysis of the formation of demand for foreign labor (Vakulenko and Leukhin, 2015).

A separate niche is occupied by studies on the sectoral employment of migrants, their enclavement and the formation of migrant employment in the national economy and individual regions (Ryazantsev, 2016a; Chudinovskih, Denisenko and Mkrtchyan, 2013). Another closely related category of studies is research on the dependence of the labor market, in particular industry-wise, on foreign labor (Tyuryukanova, 2007; Ivakhnyuk, 2012). An independent area of study is the assessment of the economic efficiency of attracting and engaging foreign labor by comparing the tax deductions and the benefits received (Vorobieva, 2005), evaluating the labor 


\section{ENTREPRENEURSHIP AND SUSTAINABILITY ISSUES}

ISSN 2345-0282 (online) http://jssidoi.org/jesi/

2019 Volume 6 Number 3 (March)

http://doi.org/10.9770/jesi.2019.6.3(11)

potential of migrants and the level of threats to migration (Vasil'eva, 2015), or the effective employment of migrant workers (Solovieva, 2016).

The first publications involving the sociological and ethnocultural approaches of the western scientific school were devoted to the biographical description of the life of labor migrants in the US and other countries. They appeared in the first quarter of the 20th century, in many respects, thanks to the representatives of the Chicago sociological school. It is their methodology used, the results obtained and the findings made that formed the basis for modern research in describing and analyzing the portrait and life of a migrant worker (Thomas and Znaniecki, 1918; Apitzch and Siouti, 2007). Later, the western sociological scientific school began to consider the problems of the impact of labor migration on the labor market of the host country, relying predominantly on the theory of heterogeneity of the labor market and the position of the ethnic economy proposed by the economic science school, studying the economic behavior of a labor migrant in the labor market, the phenomena of ethnic employment and ethnic entrepreneurship (Bonacich, 1973; Waldinger, Aldrich and Ward, 2000; Light, 1984; Granovetter, 1995). In turn, the emergence and development of western economic sociology that considers the components of the labor market in conjunction with social ties and relations (e.g. within the family and ethnic community) proposed a number of new, now extremely topical, directions in the study of the socio-economic position of foreign workers in the labor market - socio-cultural and economic adaptation, the state of marginalization, etc. (Castells, 1975; Levanon, 2011). In recent years, as a result of the increasing intensity of migration flows in the world, especially in the light of the last migration crisis of 2014-2015 in Europe, and the widespread dissemination of social initiatives in the field of socio-cultural and economic adaptation and integration of migrants, research in the field of social innovations, including those relevant to the labor market and employment of migrant workers, became highly relevant (Buiskool and Frouws, 2010; Benton et al., 2014).

Russian followers of the sociological approach supplement the experience accumulated by foreign sociologists in studying the portrait of a labor migrant, his demographic and socio-professional profile, life path, socioeconomic status and employment conditions in the labor market (Lokshin and Chernina, 2013; Peshkova, 2016; Sosnina, 2012; Mukomel, 2012; Chudinovskih, Denisenko and Mkrtchyan, 2013; Abashin and Chikadze, 2008). In the process of formation of Russian economic sociology in the second half of XX century, the development of research in the field of ethnic employment (Dyatlov and Grigorichev, 2015) and the socio-cultural and economic adaptation and exclusion of migrants (Mukomel, 2011; Ledeneva, 2014) have also been widely developed. A rising popularity is gained by the 'new institutional approach' to the study of interaction patterns of labor migrants with the receiving environment, in particular, their involvement in migrant networks of unskilled and skilled migrants (Lisitsyn and Rezaev, 2015).

The study of labor migration from the geography viewpoint is closely related to research within the framework of economic and sociological approaches. Thus, the analysis of spatial disproportions and peculiarities of the development of labor markets of receiving territories under the influence of external labor migration is most common in the context of studying the sectoral specialization of migrant employment and segmentation of labor markets within the framework of the economic approach of 'labor geography' (Gross and Schmitt, 2012; Schovánková, 2013). On the contrary, the study of the processes and forms of resettlement of immigrants and temporary migrant workers is interdependent with research on the formation of ethnic communities, the adaptation and integration of foreign citizens into the host society, which originated mainly within the Chicago School of Sociology (in particular, the model of spatial assimilation of immigrants) and the Los Angeles Sociological School of Urban Studies (Kain, 1968; Sinning and Vorell, 2009; Vendina, 2004). Particularly interesting are rare studies in the framework of the new economic-geographic approach of 'labor geography'1, according to which the active activity of migrant workers is examined by changing the conditions, the environment, and the space of their employment (Herod, 1997; Rogaly, 2009).

Relatively young and least studied, but having a huge potential, is the research on the existing institutional features of attracting and using (i.e. 'absorbing') of migrant workers by the labor market depending on the 


\section{ENTREPRENEURSHIP AND SUSTAINABILITY ISSUES}

ISSN 2345-0282 (online) http://jssidoi.org/jesi/

2019 Volume 6 Number 3 (March)

http://doi.org/10.9770/jesi.2019.6.3(11)

territory of migration of migrants (Krasova, 2012; Denisova et al., 2014). This direction is rooted in institutional geography.

Studies on the impact of external labor migration on the development of labor markets from the point of view of the political approach are considered in the new direction of 'political migration'2. Labor migration in this context acts, on the one hand, as an object of political control and governance, on the other hand as an object of manipulation (Efimov, 2007). The first direction involves research on the impact of foreign policy on labor migration and the development and implementation of the state migration policy with regard to the attraction and use of foreign labor, the situation of migrant workers in local labor markets, including aspects of national and regional security (Bohning, 1984; Kamenskij, 1999). The last aspect since the 1990s (after the end of the Cold War) is revealed from the position of the concept of 'securitization of migration'3, which proposes to consider migration (illegal, uncontrolled) as a 'new' ('old' was military) threats to national security (Buzan et al., 1998; Guild, 2009). Later this trend became popular among Russian scientists (Vitkovskaya and Panarin, 2000; Efimov, 2007; Ioncev, 2003). However, the issues of the interrelationship between the processes of labor migration and security in the scientific environment have been touched upon much earlier. For example, in Austria, scientists emphasize that, since the 1960s the massive involvement of foreign workers caused the first cultural conflicts in society, and the economic crisis of the 1970s has only strengthened them (Jakubowicz, 2011). In the second direction, the focus is not only the speculation (manipulation) of the consequences of labor migration for the host country, including the labor market, on the part of political forces that use this in the struggle for the electorate, but also the general role of external labor migration in political processes in the host society (Golder, 2003; Freeman, 2015; Molodikova and Lyalina, 2017).

Studies on the effects of labor migration from the legal approach often rely on political science and reveal the role of a parliamentary component in the formation and implementation of an effective migration policy. The research generally includes the issues of improving the legislative base, legal support for state mechanisms for regulating migration processes, the responsibility of ministries, departments, officials, citizens for observing norms and rules established in the migration sphere, mobilizing the public for maintenance and implementation of migration policy (Kudryavtseva, 2009). Today, there can be distinguished three main research areas of the legal studies of the impact of external labor migration on the labor market of the host country. First, the legal framework for regulating the recruitment and use of migrant workers, the existing mechanisms and practices for implementing such policies, the legal framework for the interaction of donor countries and recipients of migrants, stakeholders are considered (Trachtman, 2009; Panizzon et al., 2015). Second, studies on the rights of migrant workers are devoted to the discrimination features of foreign workers of different categories (e.g. domestic workers, undocumented migrants, women, disabled persons, etc.) in the labor market and mechanisms for preventing violations of their rights and freedoms (Bohning, 1988; Ioncev, 2005). Third, preventing and combating the phenomena of informal and illegal employment, exploitation, as well as human trafficking among migrant workers. Illegal, undocumented migration has been recognized as one of the main migration problems since ancient times, to combat which the migration legislation is directed. The publications of OECD (OECD, 2000) and Gulina (Gulina, 2013) place accent on the challenges associated with such migration to host countries and regions (primarily illegal employment), determining the most effective legal mechanisms of counteractions.

\section{Labor market security - contextual framework for diagnosing risks and threats in the sphere of external labor migration}

The urgency of developing a new research direction in migration studies is due, on the one hand, to the multidimensionality of migration consequences for the labor market, including the provision of economic, social and other types of national security, on the other hand, those roles that the labor market fulfills. The proposed new research direction in migration studies is comprehensive, that is, it is designed to provide an interdisciplinary 


\section{ENTREPRENEURSHIP AND SUSTAINABILITY ISSUES}

ISSN 2345-0282 (online) http://jssidoi.org/jesi/

2019 Volume 6 Number 3 (March)

http://doi.org/10.9770/jesi.2019.6.3(11)

multilateral review of external labor migration as a relatively holistic object of research without taking into account its internal structure and the interrelationships of its individual elements.

The labor market within the framework of the concept of sustainable development of the territory should be viewed as an object of regulation, through which such development is provided. For the purposes of this study, the definition of the term "sustainable development" is based on that formulated by the United Nations in the Report of the World Commission on Environment and Development: Our Common Future in 1987. "Sustainable development is development that meets the needs of the present without compromising the ability of future generations to meet their own needs" (United Nations, 1987) (article 2 Part 1). At the same time, Russian legislation emphasizes that one of the most important conditions for state regulation of the transition to sustainable development is the creation of a well-established system of interaction "center-regions" and ensuring the sustainable development of all regions of Russia (O Koncepcii, 1996).

In this context, understanding the concept of "sustainable development of the territory", which is defined in The Town-Planning Code of the Russian Federation is extremely important. "Sustainable development of the territories - providing when implementing town-planning activities of safety and favorable conditions for life activity of the person, restriction of negative impact of economic and other activity for the environment and ensuring protection and rational use of natural resources for the benefit of these and future generations" (The town-planning code, 2004) (article 1). In order to ensure sustainable development of the territory, the labor market of this territory should function in such a way that present and future generations have an alternative life support system, consisting of stable employment and diversified sources of income (Tret'iakova, 2014) (p. 28).

At the same time L. Tretyakova developed the conceptual provisions for the labor market development in the context of ensuring sustainability. She interprets the sustainable development of the labor market as "the stable development of social and labor relations, ensuring the demand for labor potential in order to achieve long-term growth in the efficiency of the regional economy, improve the quality and standard of living of the able-bodied population" (Tret'iakova, 2014) (p. 30). And the strategic goal of sustainable development of the labor market she sees "the formation of the objective economic conditions for demand of labor potential, stimulating labor demand and promote the growth of wages and incomes of able-bodied population" (Tret'iakova, 2014) (p. 31). Proceeding from these provisions, the sustainable development of the labor market should be ensured by the balance of human life in the social sphere, the economy and the sphere of innovation, geopolitics and ecology. Figure 2 shows schematically the main components of sustainable development of the labor market in conditions of attracting and using foreign labor.

Social component of sustainable development of the labor market implies satisfaction of the existing demand for legal jobs by local residents, as well as creation of conditions for the qualitative development of the labor potential of the population and professional growth. Maintaining a balance of sustainability of the social sphere will help improve the quality and standards of living of the able-bodied population.

Economic and innovative component implies meeting the demand for workers by employers and ensuring a high level of labor potential of the labor force that will enhance the efficiency of the labor market and long-term growth of the economy of the host territory.

Geopolitical component consists in ensuring the balance in using internal and external labor resources represented by the maximum number of third countries, as well as increasing the prestige of the jobs of the regional labor market on the world stage. To a large extent, this will ensure the independent development of the labor market itself and the host country.

From the environmental point of view, the labor market should ensure the preservation of human health, as a part of nature, and the environment. Substantially this can be achieved through using the labor-saving technologies 
and increasing the level of safety of jobs, labor protection, and increasing the number of "green" jobs that contribute to the environmental preservation and environmental regeneration.

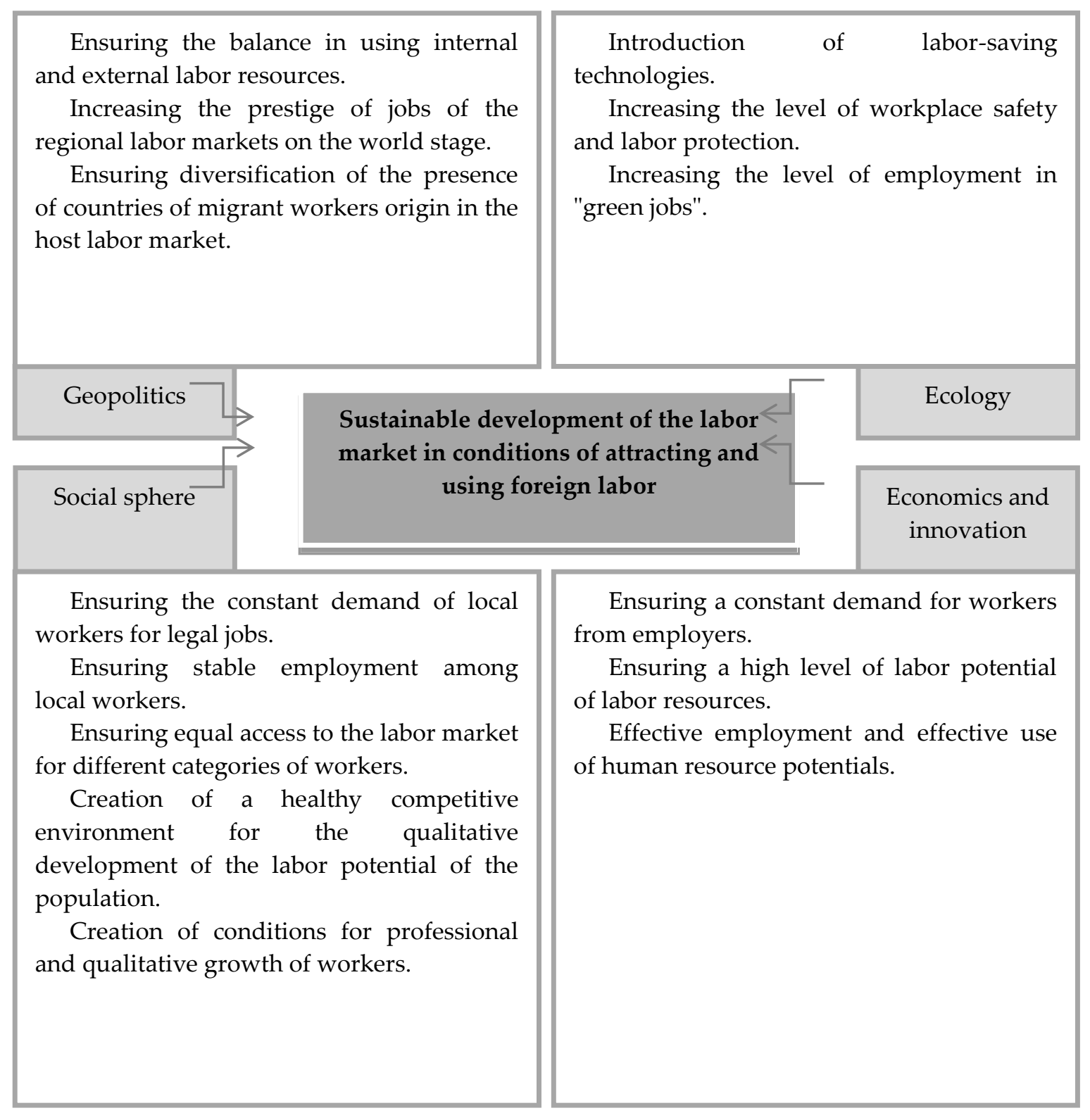

Fig. 2. Components of sustainable labor market development in the context of attracting and using foreign labor. Source: Own elaboration.

Security is one of the criteria for the sustainable development of the labor market. The notion of "labor market safety" today does not have a well-established scientific definition. Usually this term is considered as one of the 
components of the economic security of the territory. However, taking into account the fact that the labor market fulfills not only economic, but also social, innovative and geopolitical functions, it is necessary to understand what place the labor market occupies in providing, respectively, social, innovation and geopolitical security.

Figure 3 schematically shows the place of the labor market in providing economic, social, innovative and geopolitical security.

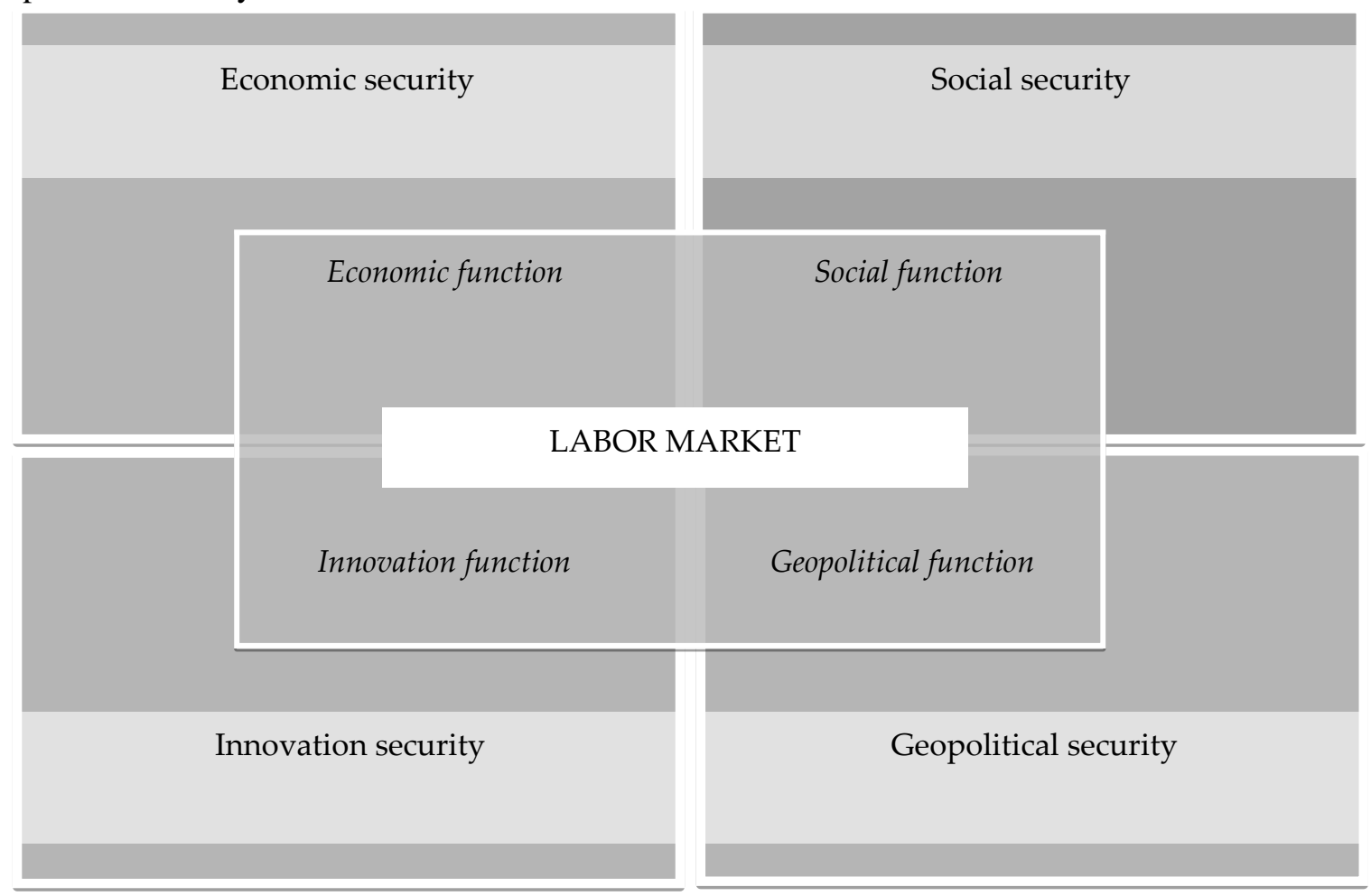

Fig. 3. Labor market in the structure of some elements of national security.

Source: Own elaboration.

Through the rational involvement, placement, regulation and use of labor, the labor market fulfills an economic function and affects economic security. From the economic security viewpoint, the labor market is its most important element, and the phenomena on the labor market can act both as a factor of ensuring its security and as a factor that enhances the threats and risks of this security (Kapranova, 2000). Employment, according to Kapranova (Kapranova, 2000. P. 145), "is an indicator that assesses ... the state of economic security of the national economy". Its lack of able-bodied population is, according to Alonkina (Alonkina, 2008), the most significant security threat. Unemployment, especially the hidden one, attributed by Professor A. Orlov (Orlov, 1995. P. 112) to the social threats to economic security, is a 'delayed-action mine' laid down under the labor market in the transition period". The labor market should function in such a way as to ensure its stability and sustainability in the event of crises and geopolitical changes and for future development, independence from external labor resources, competitiveness in world labor markets, creation of decent living conditions for every member of society.

Providing a normal level of income and welfare of the population, a stable level of reproduction of the productive abilities of workers, the labor market realizes a social function and ensures social security. As a system of socioeconomic relations between the employer, the employee and the state, within the framework of the theory of social security, the labor market must ensure the life and activity of society stable and sustainable to external and internal adverse impacts and shocks, preserve its integrity, independence and the ability to reproduce and progress. After all, the problems of employment and unemployment as social threats can lead and often lead to a 


\section{ENTREPRENEURSHIP AND SUSTAINABILITY ISSUES}

ISSN 2345-0282 (online) http://jssidoi.org/jesi/

2019 Volume 6 Number 3 (March)

http://doi.org/10.9770/jesi.2019.6.3(11)

worsening of the social microclimate and a decrease in the level and quality of life of individuals and society as a whole (Orlov, 1995; Bochko, 2011).

Accumulating, adapting and supporting the critical mass of labor resources of a certain level of qualification (especially high) and specialization that meets the structural needs of the territory's economy and strategic directions of its development, effectively using the labor potential of workers (including through innovative selfemployment), the labor market fulfills the innovative function and contributes to the provision of 'innovation security' (Mikhaylova and Mikhaylov, 2015). The role of the labor market in ensuring innovation security is to create the factors and conditions for the formation and maintenance of the reproduction and self-development necessary for sustainable and effective innovative development of the labor economy while maintaining a sufficient level of independence from external labor resources.

The integration of the national labor market into the international labor market, on the one hand, balances the domestic demand and supply, and, on the other, forms the dependence on external labor resources and a partial loss of independence, which determines the impact on geopolitical security. The labor market from the point of view of ensuring geopolitical security should be considered in the context of the concept of geo-economics, which is its constituent element (Luttwak, 1998). The integration of the national labor market into the world labor market as a result of globalization, both through the participation of its own labor resources in the labor markets of other countries, and through the reception of migrant workers on its territory, causes close economic integration and interdependence of the states involved. Thus, the labor market acts as a regulator of this interaction and, in order to ensure geo-economic and geopolitical security, it must function in such a way as to prevent possible geo-economic conflicts caused by competition for labor resources, create conditions for the development of human capital to enhance the state's competitiveness in the international arena, to prevent the deformation of supply in the national labor market as a result of international migration (primarily, labor). Acknowledging the importance of the labor market in the formation and maintenance of the economic, social, innovative and geopolitical security of the state or a single region, it is necessary to ensure the security of the labor market itself by minimizing or eliminating external and internal risks and threats or improving their governance efficiency. Since the low level of labor market security makes it difficult to achieve other types of national security.

Theoretical interpretation of the "economic security of the labor market predetermines the realization of all vital interests of the individual, family, enterprise, society, state, even if not, at first glance, of an economic nature" (Alonkina, 2008. P. 39). The notion of 'labor market security' is generally considered as the welfare factor of the working population and reflects those aspects of economic security that are associated with the risk of job loss and its consequences for workers and their families (Hijzen and Menyhert, 2016). This approach to determining the security of the labor market does not coincide with the Russian interpretation, which focuses on analyzing external and internal risks and threats to the labor market, factors that ensure its security, which is rather comparable to understanding the role of the labor market in ensuring social and economic security, in this case, of an individual. Therefore, the term 'labor market safety' is often replaced by the concepts of 'job security' and 'career and employment security' (Pacelli et al., 2008; Green, 2011). Recently, the term 'flexicurity labor market', similar to the interpretation, has also become widely used, which means "the type of labor law policy, that is, such a direction of activity of the state (its bodies) and organizations, which manifests itself in the combination of flexibility in regulating labor and related relations and in the governance of the labor market, ensuring the protection (guarantee) of the rights of subjects of labor law" (Tomashevskij, 2011. P. 156).

The consideration of risks and threats to the functioning of the labor market takes place outside the unified labor market security theory, but separately in the aggregate of factors that affect it, both positively and negatively. The problems of demographic (e.g. population aging and the influx of migrants; Henschel et al., 2008) and social (Mondéjar-Jiménez et al., 2009) development, globalization (Siedel, 2007) and many others are being discussed. 


\section{ENTREPRENEURSHIP AND SUSTAINABILITY ISSUES}

ISSN 2345-0282 (online) http://jssidoi.org/jesi/

2019 Volume 6 Number 3 (March)

http://doi.org/10.9770/jesi.2019.6.3(11)

Thus, the analysis of existing literature has revealed considerable shortcomings in the conceptualization of a single integrated concept of labor market security, taking into account possible approaches to its definition and awareness of its significance for ensuring social, economic, innovative and geopolitical security.

Labor market security can be viewed from four different aspects within the framework of existing approaches to the definition of security (Mikhaylova, 2015): firstly, as an independent system, the security of the labor market can be defined as an integral complex system of protecting the vital interests of the country and society, the rights and freedoms of the individual in the national and international labor market, ensuring its independence, efficiency, competitiveness, stability and sustainability, and the ability to develop. Secondly, as a state of protection, when a national (regional or local) market is secure from external and internal threats and risks, the citizens' needs, rights, and freedoms are met, and the state develops rapidly and efficiently while maintaining its competitive advantages over other global market participants. Thirdly, as the ability of the labor market to protect the vital values and interests of the individual, society and the state as a whole, to resist negative internal and external influences, to maintain their independence and self-sufficiency, competitiveness, integrity, balance and sustainability, ability to develop and progress. Fourthly, from the perspective of conditions and factors of the existence of the labor market, it can be defined as a set of conditions and factors of the functioning of the national (regional or local) labor market that ensure its sustainable economic, social, innovative, geopolitical development, efficiency and competitiveness, independence from external resources, ability to resist destructive external and internal influences.

The difference between regional labor market security and the national one lies in the spatial localization of the protection object (in fact, the labor market), the conditions and factors of its functioning, and the developmental risks and threats generated, the presence and depth of risks and threats, including those arising from the relationship with the federal center and other regions. Proceeding from the labor market functions identified, it is advisable to consider its security as a set of four integral components: economic, social, innovation and geopolitical, which determine the role of the labor market in ensuring economic, social, innovation and geopolitical security, respectively.

\section{The role of external labor migration in ensuring labor market security as a new direction of research}

External labor migration represents an impact on the development of the receiving territory from the outside, therefore the risks and threats, the factors caused are external and determine the external security of the labor market (Vitkovskaya and Panarin, 2000). However, at the same time, the multiplicative effect caused, in particular, expressed in the improvement of the education system as a result of the change in supply in the labor market, is already considered as internal.

The place of migration in ensuring the labor market security is largely determined by the role it plays in ensuring economic, social, innovation and geopolitical security - on the one hand, it plays the role of a security factor, on the other - the role of a real or potential threat. In particular, effective migration is seen as a sustainability factor of the social sphere of life, the ability to withstand the migration outflow of the population is a security factor in the social sphere of life, uncontrolled (unorganized and illegal) migration (and in some jobs, external labor migration in general) is clearly classified as a threat to sustainable development of a country, due to its negative impact on the level of crime and development of the labor market, including "the destruction of the national labor market, a drop in the level of wages, the displacement of Russians from the labor market, an increase in unemployment among the local population" (Tatarkin et al., 2008. P. 160).

Publications of Vitkovskaya and Panarin (Vitkovskaya and Panarin, 2000), Malakha (Malakha, 2005), Ioncev (Ioncev, 2003), and others, devoted to risks and threats, factors of ensuring national and regional economic, social, innovation, geopolitical security, conditioned by external labor migration, made it possible to single out the 


\section{ENTREPRENEURSHIP AND SUSTAINABILITY ISSUES}

ISSN 2345-0282 (online) http://jssidoi.org/jesi/

2019 Volume 6 Number 3 (March)

http://doi.org/10.9770/jesi.2019.6.3(11)

main ones that determine the development of the labor market for migrant-receiving territory. Previously identified risks and threats, labor market security factors have been supplemented by new potential (in particular, geopolitical ones), grouped according to the nature of attracting and using migrant workers in the receiving country and correlated with labor market security components that are affected (Figure 4).

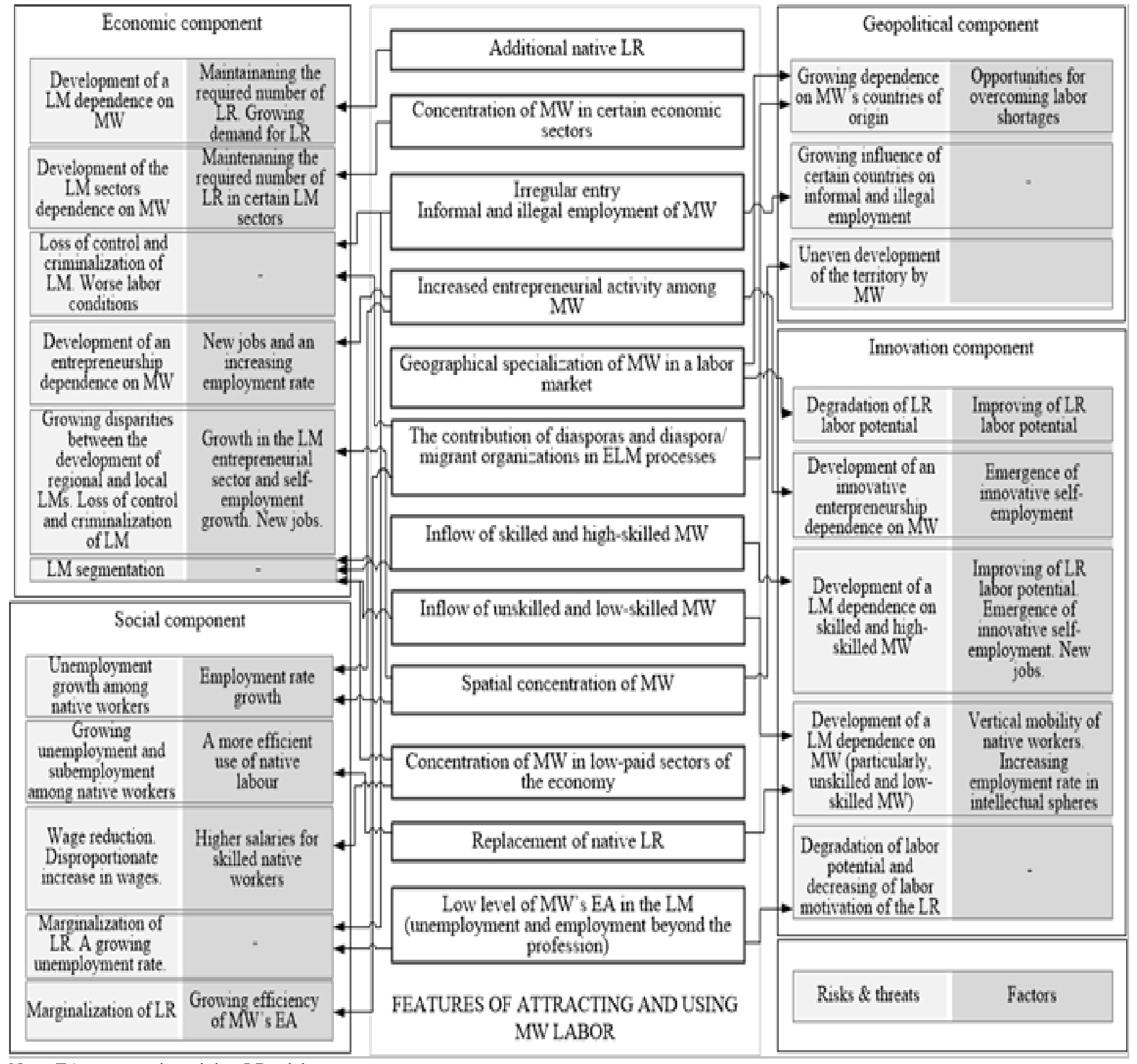

Note: EA - economic activity; LR - labor resources.

Fig. 4. Risks, threats, and factors associated with the components of the host local market security in the context of external labor migration. Source: Own elaboration 


\section{ENTREPRENEURSHIP AND SUSTAINABILITY ISSUES}

ISSN 2345-0282 (online) http://jssidoi.org/jesi/

2019 Volume 6 Number 3 (March)

http://doi.org/10.9770/jesi.2019.6.3(11)

The broadest variety of risks and threats the external labor migration brings to the economic and innovation components of labor market security, stipulating not only dependence on migrant workers, but also degradation of labor potential (in the case of low and unskilled labor and / or low level of economic adaptation), further segmentation, growth of disproportions in the development of regional and local labor markets. Risks and threats to the social component of labor market security are expressed mainly in changing the socio-economic status and employment of workers from among the local population. The nature of risks and threats to the geopolitical component of labor market security is associated with the growth of the influence of individual countries on the development of the labor market. At the same time, it is important to note that the undocumented migration and the associated informal and illegal employment of migrant workers are the greatest danger in terms of the depth and variety of risks and threats. An inflow of migrant workers without or with low qualifications also plays an important role. However, the external labor migration is not only and the not only source of risks and threats, but also a factor of ensuring the security of the labor market, which is primarily due to its reproductive, redistributive and selective functions (Sitarchuk, 2012). This testifies to the possibility and necessity of regulating external labor migration, and not universal restriction or, on the contrary, easing it.

One of the most significant risks in the long term is the growing dependence of the labor market on migrant workers. A conceptual interpretation of the term 'labor market dependence' on foreign labor, migrant workers is based on the development of the 1970s' theory of dependent development (Frank, 1972; Baran, 1973). According to the latter, international migration is cementing the relationship of the less developed countries to the more developed ones. Later, the theorists of globalization stated that the modern picture of the world has changed significantly, and today it is a matter of mutual dependence, mutual co-ordination of socio-economic development of countries through the formation of world trade markets and labor, international cooperation of production, etc. To determine the role of international migration in the workforce development of territories Ivakhnyuk (Ivakhnyuk, 2012) introduces and uses the concept of 'migratory interdependence'. The author rightly emphasizes the dependence of the less developed countries on the possibility of "access to the labor markets of other states for some of their relatively surplus population" and the more developed countries from replenishment of the labor shortage by importing migrant workers or transferring labor-intensive industries to countries with a relatively low payment (ibid. 2012). Speaking about the Eurasian migration system, Ivakhnyuk notes that mutual migration dependence "is expressed in the growing interest in interstate cooperation in the field of international migration in the format of regional organizations" and is a long-term factor in the development of post-Soviet Eurasia, which causes a reduction in the risks of regional economic and demographic imbalances (ibid. 2012).

Moving away from the understanding of the dependence from the point of view of its bilaterality, which Ivakhniuk suggests, it is worthwhile to consider other views and approaches to understanding the dependence of the receiving territory on migrant workers, in order to further define the boundaries of the concept of 'migration dependence of the labor market of the host territory from the foreign worker force'. In 2004 S. Castles attempted to give a broad definition of the term 'structural dependence on immigrant labor'. He understands it as the state of the country's economy when it cannot function without migrants, despite the high level of unemployment, because migrant workers are concentrated in jobs that local workers cannot or do not want to replace (Castles, 2004). Later, Martin (Martin, 2010), Abella and Martin (Abella and Martin, 2016) have introduced the term 'path dependence' with regard to dependence on migrant workers, which is widely used today, meaning employers' dependence on the initially chosen path for filling vacancies by foreign workers, relying on its availability in the future. At the same time, the authors focus on the most popular and attractive vacancies for migrants - with low pay, often with unsatisfactory working conditions. Despite the fact that today the dependence on foreign labor is attributed by the Union of International Associations (UIA) to the number of world problems in the category "G: very specific problems" (Dependence on foreign labour, n.d.), so far the essence of this dependence is not revealed, featuring a dependence of individual labor-consuming industries on a low-skilled labor.

When determining the boundaries of dependence on foreign labor, firstly, it is necessary to identify to which object this dependence relates - the employer, the economy as a whole, the labor market. In the context of this 


\section{ENTREPRENEURSHIP AND SUSTAINABILITY ISSUES}

ISSN 2345-0282 (online) http://jssidoi.org/jesi/

2019 Volume 6 Number 3 (March)

http://doi.org/10.9770/jesi.2019.6.3(11)

paper, the dependence of the labor market of the host territory is considered. Secondly, it is necessary to specify, the subject of research - all migration in general or its separate types. Current study focused on external labor migration. Thirdly, it is extremely important to take into account the diversity of real and potential risks and threats to the labor market caused by external labor migration. From this point of view, the following definition of the dependence of the labor market of the host country on the foreign labor force is proposed: it is a state of the labor market in which its sustainable and stable functioning is largely determined by the constancy of the volumes and the set of qualitative characteristics of external labor resources. At the same time, the dependence of the labor market on the foreign labor force includes the dependence of the labor market as a whole, its individual niches and segments on: a) foreign workers of different levels of qualifications and education, the country of origin; and b) foreign employers (entrepreneurs).

\section{Conclusions}

The systematization of the studies on the consequences of labor migration for the labor market of the host country has shown that up to date there are more than two dozen research areas predominantly in the framework of economic and sociological scientific schools. The analysis suggest that despite the fact that the issues of regulating the processes of labor migration in the context of ensuring national and regional security have been considered for almost 50 years from the perspective of the concept of 'securitization of migration' within the framework of the political science approach, the concept of labor market security in the sphere of external labor migration is not yet formulated. The provisions of this scientific direction are largely not integrated with the results of research on the impact of labor migration on the labor market in other research areas and schools; its potential has not been revealed.

The proposed approach to the justification of the term labor market security made it possible to unite its role in providing economic, social, innovation and geopolitical security and to single out four components of labor market security on this basis. Within these components, it seems most appropriate to consider the risks and threats arising from external labor migration in the labor markets.

Labor market security in the sphere of external labor migration can serve as an independent research topic on the effects of labor migration on host labor markets. The originality of the scientific direction consists in studying external labor migration as a relatively holistic object of research, taking into account the whole complex of possible consequences for labor market. At the same time, both positive conditions and factors of the labor market balance, as well as possible risks and threats, are taken into account. The scientific direction is one of economic and geographical, as it is intended for regional studies and allows revealing the spatial heterogeneity of the migrant receiving territories, both in determining their need for additional labor resources among migrant workers, and in the possible consequences of their use in the economies of the regions. The interdisciplinarity also determines the originality of the scientific direction. The proposed direction of research took its position at the intersection of existing 23 research directions within the framework of 5 scientific approaches, classified as a result of theoretical substantiation of a new direction. The theoretical basis of the new direction of research is the concept of sustainable development, but also uses the provisions of security theory and the concept of securitization of migration, labor geography. The concept of the balance of the labor market is understood more widely than is customary - not only from the position of market equilibrium between supply and demand, and also taking into account other balances. Within the framework of the new direction, it was suggested to study the impact of external labor migration on the labor market balance in the economic, social, innovative, ecological and geopolitical spheres. The risks and threats to labor market security, determined by external labor migration, can be statistically measured, which predetermines the practical applicability of the work in this direction. And the analysis based on the diagnosis of risks and threats will enable formulating recommendations for the modernization of migration policy in order to ensure the security of the host labor market, justifying the importance of research in this area. 


\section{List of abbreviations}

EA - economic activity

ELM - external labor migration

LM - labor market

LR - labor resources

MW - migrant workers

UIA - Union of International Associations

US - United States of America

USSR - Union of Soviet Socialist Republics

\section{Endnotes}

${ }^{1}$ The term "labor geography" introduced by A. Herod in 1997 stands for a separate sub-branch of the school of socio-economic geography (the term does not occur in the Russian-language literature), which studies the active role of workers in the territorial organization of the economic life of society, ensuring its own survival and reproduction.

2 The term "political migrationology" appeared in 2005 thanks to the work of the Russian political scientist Y. Efimov. Political migration is understood as the "branch of political knowledge, the object of which is migration processes as part of political reality, and the subject - the trends of its development and changes associated with the politicization of migration processes, with the emergence of political components in migration processes, aimed at constituting, institutionalizing, transforming political reality".

${ }^{3}$ The concept of "securitization of migration" was proposed by B. Buzan and O. Waever from the Copenhagen School of Security Studies (Copenhagen Peace Research Institute) in 1998.

\section{References}

Abashin, S., \& Chikadze, E. (2008). Economicheskie migranty iz Tsentralnoi Azii: issledovanie transformatsii identichnosti, norm povedeniya i tipov sotsialnykh svyazei [Economic Migrants from the Central Asia: Research on Identity Transformation, Everyday Rules and Types of Social Networks]. Available on the Internet: http://cisr.ru/files/otchet_econom_mogranty.pdf

Abella, M., \& Martin, P. (2016). Guide on measuring migration policy impacts in ASEAN. Bangkok: ILO.

Alonkina, L. I. (2008). Gosudarstvennoe regulirovanie rynka truda v kontekste obespecheniya ehkonomicheskoj bezopasnosti Rossii [State regulation of the labor market in the context of ensuring economic security in Russia]. Akademiya upravleniya MVD RF: doctoral thesis. Available on the Internet: http://dlib.rsl.ru/viewer/01003459599\#?page=40

Angrist, J. D., \& Kugler, A. D. (2001). Protective or counter-productive?: European labor market institutions and the effect of immigrants on EU natives. Cambridge MA: National Bureau of Economic Research.

Apitzch, U., \& Siouti, I. (2007). Biographical Analysis as an Interdisciplinary Research Perspective in the Field of Migration Studies. Frankfurt am Main: Johann Wolfgang Goethe Universität.

Baran, P. (1973). On the political economy of backwardness, in Wilber, C. K. (Ed.). The Political Economy of Development and Underdevelopment. New York: Random House, 82-93.

Barro, R. J., \& Sala-i-Martin, X. (2003). Economic growth. $2^{\text {nd }}$ ed. Cambridge, Mass.: The MIT Press.

Benton, M., Sumption, M., Alsvik, K., Fratzke, S., Kuptsch, C., \& Papademetriou, D. G. (2014). Aiming higher: policies to get immigrants into middle-skilled work in Europe. Washington, D.C.: MPI. 


\section{ENTREPRENEURSHIP AND SUSTAINABILITY ISSUES}

ISSN 2345-0282 (online) http://jssidoi.org/jesi/

2019 Volume 6 Number 3 (March)

http://doi.org/10.9770/jesi.2019.6.3(11)

Bochko, M. E. (2011). Social'naya bezopasnost' i riski na rynke truda [Social security and labour market risks]. NAUKA YUURGU. Sekcii ehkonomiki, upravleniya i prava: materialy 63-j nauch. konf. [SCIENCE SUSU. Section of Economics, Management and Law: materials of 63rd scientific conference]. Chelyabinsk: Publishing Center of South Ural State University, 30-33.

Bohning, W. R. (1984). Guest Worker Employment - Lessons for the USA? In: Bohning, W. R. (Ed.). Studies in International Labor Migration. London: The Macmillan Press Ltd, 123-164.

Bohning, W. R. (1988). The Protection of Migrant Workers and International Labour Standards. International Migration, 26(2), 133-146. https://doi.org/10.1111/j.1468-2435.1988.tb00618.x

Bonacich, E. A. (1973). Theory of Middleman Minorities. American Sociological Review, 38(5), 583-594. https://doi.org/10.2307/2094409 Borjas, G.J. (1987). Self-Selection and the Earnings of Immigrants. American Economic Review 77(4): 531-553. https://doi.org/10.3386/w2248

Borjas, G.J. (2003). The Labor Demand Curve Is Downward Sloping: Reexamining The Impact Of Immigration On The Labor Market. The Quarterly Journal of Economics, 118(4), 1335-1374. https://doi.org/10.1162/003355303322552810

Boswell, C., \& Straubhaar, T. (2004). The Illegal Employment of Foreign Workers: an Overview. Intereconomics, 39(1), 4-7. https://doi.org/10.1007/bf03032198

Braun, T., \& Weber, H. (2016). How do regional labor markets adjust to immigration? a dynamic analysis for post-war Germany. Frankfurt am Main: Deutsche Bundesbank, Eurosystem.

Buiskool, B. J., \& Frouws, B. (2010). Migrants to Work: Innovative approaches towards successful integration of third country migrants into the labour market. Final report. Available on the Internet: https://ec.europa.eu/migrantintegration/index.cfm?action=media.download\&uuid=29DA3117-E6B3-6CF0-E678A9B484C4C5EB

Buzan, B., Wæver, O., \& Wilde, J. (1998). Security: a new framework for analysis. Boulder, CO: Lynne Rienner Publishers.

Castells, M. (1975). Immigrant Workers and Class Struggles in Advanced Capitalism: The Western European Experience. Politics \& Society, 5(1), 33-66. https://doi.org/10.1177/003232927500500102

Castles, S. (2004). Why Migration Policies Fail. Ethnic and Racial Studies, 27(2), 205-227. https://doi.org/10.1080/0141987042000177306

Castles, S., \& Kosack, G. (1973). Immigrant workers and class structure in Western Europe. Oxford: Oxford University Press.

Chiswick, B.R., \& Hurst, M. (1998). The Labor Market Status of Immigrants: A Synthesis, in: Kurthen, H. et al. (Eds). Immigration, Citizenship, and the Welfare State: Germany and the United States in Comparison. Stamford, CT: JAI Press, 73-94.

Chudinovskih, O. S., Denisenko, M. B., \& Mkrtchyan, N. V. (2013). Vremennye trudovye migranty v Rossii [Temporary labour migrants in Russia]. Demoscope Weekly, 579-580. Available on the Internet: http://demoscope.ru/weekly/2013/0579/demoscope579.pdf

Denisova, G. S., Rozin, M. D., Sushchiy, S. Ya., Tumakova, Zh. A., \& Androsova, S. V. (2014). The attitude towards labor migrants in the south of Russia: integration prospect in the conditions of external calls. Engineering Journal of Don, 31(4-1), p. 98.

Dependence on foreign labour (n.d.). In: The encyclopedia of world problems and human potential. Available on the Internet: http://encyclopedia.uia.org/en/problem/152300

Dyatlov, V. I., \& Grigorichev, K. V. (Eds.) (2015). Ethnic Markets in Russia: Space of Bargaining and Place of Meeting. Irkutsk: Irkutsk State University Publishing.

Efimov, Yu. G. (2007). Migraciya v sovremennom politicheskom processe [Migration in the modern political process]. Stavropol'skij gosudarstvennyj universitet: doctoral thesis. Available on the Internet: http://search.rsl.ru/ru/record/01003389593

Ekberg, J. (2004). Immigrants in the welfare state, in Södersten, B. (Ed) Globalization and the Welfare State. New York: Palgrave MacMillan, 195-212.

Frank, A. G. (1972). The Development of Underdevelopment. Dependence and Underdevelopment. New York: Anchor Books. 


\section{ENTREPRENEURSHIP AND SUSTAINABILITY ISSUES}

ISSN 2345-0282 (online) http://jssidoi.org/jesi/

2019 Volume 6 Number 3 (March)

http://doi.org/10.9770/jesi.2019.6.3(11)

Freeman, G. (2015). Immigrant Labor and Racial Conflict in Industrial Societies. Princeton: Princeton University Press.

Golder, M. (2003). Explaining Variation In The Success Of Extreme Right Parties In Western Europe. Comparative Political Studies, 36(4), 432-466. https://doi.org/10.1177/0010414003251176

Granovetter, M. (1995). The Economic Sociology of Firms and Entrepreneurs, in Portes, A. (Ed.). Economic Sociology of Immigration. The: Essays on Networks, Ethnicity, and Entrepreneurship. New York: Russell Sage Foundation, 128-165.

Green, F. (2011). Unpacking the misery multiplier: How employability modifies the impacts of unemployment and job insecurity on life satisfaction and mental health. Journal of Health Economics, 30(2), 265-276. https://doi.org/10.1016/j.jhealeco.2010.12.005

Gross, D. M., \& Schmitt, N. (2012). Temporary Foreign Workers and Regional Labour Market Disparities in Canada. Canadian Public Policy, 38(2), 233-263. https://doi.org/10.1353/cpp.2012.0020

Guild, E. (2009). Security and Migration in the 21st Century. Cambridge: Polity Press.

Gulina, O. R. (2013). Pravovaya otvetstvennost' za najm nelegal'nyh migrantov: opyt ES $i$ SSHA [Legal Responsibility for Hiring Illegal Migrants: EU and US Experience]. St. Petersburg: Institute for the Rule of Law at the European University at Saint-Petersburg.

Henschel, B., Pohl, C., \& Thum, M. (2008). Demographic Change and Regional Labour Markets: The Case of Eastern Germany. Munich: Center for Economic Studies \& Ifo Institute for Economic Research.

Herod, A. (1997). From a Geography of Labor to a Labor Geography: Labors Spatial Fix and theGeography of Capitalism. Antipode, 29(1), 1-31. https://doi.org/10.1111/1467-8330.00033

Hijzen, A., \& Menyhert, B. (2016). Measuring Labour Market Security and Assessing its Implications for Individual Well-Being. OECD Social, Employment and Migration Working Papers No. 175. Paris: OECD Publishing.

International Labour Office. (2015). ILO Global estimates of migrant workers and migrant domestic workers: results and methodology. Retrieved from: http://www.ilo.org/wcmsp5/groups/public/\%40dgreports/\%40dcomm/documents/publication/wcms 436343.pdf

International Migration Report 2017: Highlights. (2017). United Nations, Department of Economic and Social Affairs, Population Division. ST/ESA/SER.A/404. $\quad$ Retrieved from: http://www.un.org/en/development/desa/population/migration/publications/migrationreport/docs/MigrationReport2017_Highlights.pdf

Ioncev, V. A. (Ed.). (2005) Trudovaya migraciya. Voprosy upravleniya i zashchity prav trudyashchihsya-migrantov $v$ Rossii [Labour migration. Issues of governance and protection of the rights of migrant workers in Russia]. Moscow: TEIS.

Ioncev, V. A. (Ed.). (2003). Migration and National Security. Scientific Series: International Migration of Population: Russia and the Contemporary World, vol 11. Moscow: MAX Press.

Ioncev, V. A., \& Ivakhnyuk, I. V. (2012). Analiticheskij Doklad po proektu na temu: Rol' mezhdunarodnoj trudovoj migracii dlya ehkonomicheskogo razvitiya Rossii [Analytical Report on the Project: The Role of International Labor Migration for the Economic Development of Russia], CARIM-East RR 2012/28. San Domenico di Fiesole: European University Institute.

Ivakhnyuk, I. V. (2012). Migracionnaya vzaimozavisimost'. CHast' II «Evrazijskaya migracionnaya sistema: ot ehkonomicheskogo pragmatizma $k$ vozrozhdeniyu civilizacionnogo edinstva» [Migratory interdependence. Part II "The Eurasian migration system: from economic pragmatism to the revival of civilizational unity”]. Available on the Internet: http://www.gumilev-center.az/migracionnayavzaimozavisimost

Jakubowicz, L. (2011). Migration and Security - an Unusual Perspective? SIAK-Journal - Journal for Police Science and Practice, 1, 2639.

Kain, J. F. (1968). Housing Segregation, Negro Employment, and Metropolitan Decentralization. The Quarterly Journal of Economics, 82(2), 175-197. https://doi.org/10.2307/188589

Kamenskij, A. N. (1999). Problemy mezhdunarodnogo trudovogo obmena i Rossiya [Problems of international labour exchange and Russia]. Moscow: Moscow Public Science Foundation. 


\section{ENTREPRENEURSHIP AND SUSTAINABILITY ISSUES}

ISSN 2345-0282 (online) http://jssidoi.org/jesi/

2019 Volume 6 Number 3 (March)

http://doi.org/10.9770/jesi.2019.6.3(11)

Kapranova, S. E. (2000). Zanyatost' kak indikator ehkonomicheskoj bezopasnosti [Employment as an indicator of economic security]. Kazanskij finansovo-ehkonomicheskij institut: PhD thesis. Available on the Internet: http://dlib.rsl.ru/01000288098

Khomra, A. U. (1979). Migratsiya naseleniya: voprosy teorii i metodiki issledovaniya [Population shift: questions of the theory and research methodology]. Kiev: Naukova dumka Publ.

Krasova, E. V. (2012). Inostrannaya rabochaya sila v mirovoi i regional'noi ekonomike: sovremennye aspekty gosudarstvennogo regulirovaniya [Foreign labour force in the world and regional economy: today's aspects of governmental regulation]. Vladivostok: VGUES Publ.

Kudryavtseva, L. V. (2009). Pravovye problemy obespecheniya ehkonomicheskoj bezopasnosti gosudarstva v usloviyah ispol'zovaniya v torgovoj sfere truda inostrannyh grazhdan [Legal problems of ensuring the economic security of the state in the conditions of using foreign citizens in the trade sphere]. Scientific notes of the Russian state social University, 7(1), 155-160.

Kugler, A., \& Yuksel, M. (2008). Effects of Low-Skilled Immigration on U.S. Natives: Evidence from Hurricane Mitch. Cambridge, MA: National Bureau of Economic Research.

Ledeneva, V. Yu. (2014). Modeli social'noj adaptacii i integracii trudovyh migrantov [Models of social adaptation and integration of labour migrants]. Moscow: Publishing House "Sputnik+".

Levanon, A. (2011). Ethnic social capital: Individual and group level sources and their economic consequences. Social Science Research, 40(1), 77-86. https://doi.org/10.1016/j.ssresearch.2010.09.014

Lifshits, M. (2013). The influence of migration and natural reproduction of labor force upon economic growth in the countries of the world. Applied Econometrics, 31(3), 32-51.

Light, I. (1984). Immigrant and ethnic enterprise in North America. Ethnic and Racial Studies, 7(2), 195-216. https://doi.org/10.1080/01419870.1984.9993441

Lisitsyn, P. P., \& Rezaev, A. V. (2015). Trudovye migranty v Rossii: strategii social'noj adaptacii. Teoreticheskie osnovy mezhdisciplinarnyh issledovanij $i$ prakticheskie primery issledovanij $v$ g. Ivanovo $i$ g. Sankt-Peterburg [Labor migrants in Russia: strategies for social adaptation. Theoretical bases of interdisciplinary research and practical examples of research in Ivanovo and St. Petersburg]. St. Petersburg. Available on the Internet: http://www.rfh.ru/downloads/Books/154393050.pdf

Lokshin, M. M., \& Chernina, E. M. (2013). Migrants on the Russian labor market: portrait and wages. Ekonomicheskiy Zhurnal VShE, $17(1), 41-74$

Luttwak, E. (1998). From Geopolitics to Geo-Economics: Logic Conflict, Grammar of Commerce II, in Tuathail, G., Dalby, S., Routledge, P. (Eds.). The Geopolitics Reader. New York: Routledge.

Lyalina, A. V. (2016). Theoretical approaches to labour migration effects for receiving territory. Regional research, 2(52), 66-71.

Malakha, I. A. (2005). K voprosu o vliyanii migracionnyh processov na ehkonomicheskuyu bezopasnost' [On the issue of the impact of migration processes on economic security in KHejfets, B. A. (Ed.). Ispol'zovanie inostrannoj rabochej sily: problemy i perspektivy [The use of foreign labour: problems and prospects]. Moscow: IIEPS RAS, 38-43.

Martin, P. (2010). A need for migrant labour? UK-US Comparisons, in Ruhs, M., Anderson B. (Eds.). Who Needs Migrant Workers?: Labour Shortages, Immigration, and Public Policy. Oxford: Oxford University Press, 295-323.

Mikhaylova, A. A. (2015). Region in the national security system of Russia. Social and Economic Geography, 1(1), 9-15.

Mikhaylova, A. A., \& Mikhaylov, A. S. (2015). Instruments of innovation security. International Journal of Economics and Financial Issues, 5(2), 128-135.

Molodikova, I. N., \& Lyalina, A. V. (2017). Territorial differences in the attitudes to the migration crisis in Germany: The political aspect. Baltic Region, 9(2), 60-75. https://doi.org/10.5922/2079-8555-2017-2-5

Mondéjar-Jiménez, J., Vargas-Vargas, M., Meseguer-Santamaría, M., \& Mondéjar-Jiménez, J. (2009). Impact of social factors on labour discrimination of disabled women. Research in Developmental Disabilities, 30(6), 1115-1123. https://doi.org/10.1016/j.ridd.2009.07.013 


\section{ENTREPRENEURSHIP AND SUSTAINABILITY ISSUES}

ISSN 2345-0282 (online) http://jssidoi.org/jesi/

2019 Volume 6 Number 3 (March)

http://doi.org/10.9770/jesi.2019.6.3(11)

Mukomel, V. (2011). Integration of Migrants: Challenges, Policies, Social Practices. Universe of Russia, 1(20), 34-50.

Mukomel, V. (2012). Transformaciya trudovoj migracii: social'nye aspekty [Transformation of labor migration: social aspects], in Gorshkov, M. K. (Ed.). Rossiya reformiruyuschayasya: Ezhegodnik [sbornik nauchnyih statey] [Russia in Reform: Year-Book [collection of scientific articles], Issue 11. Moscow: Novyiy hronograf, 236-263.

O Koncepcii perehoda Rossijskoj Federacii k ustojchivomu razvitiju: the Edict of the President of the Russian Federation № 440, dated 1 April 1996. (1996). Available on the Internet: http://pravo.gov.ru/proxy/ips/?docbody=\&nd=102040449\&rdk=\&firstDoc=1\&lastDoc=1

OECD. (2000). Combating the Illegal Employment of Foreign Workers. Paris: OECD Publishing.

Orlov, A. (1995). Ugrozy v social'noj sfere: ih diagnostika i vozmozhnosti uprezhdeniya [Threats in the social sphere: diagnosis and the possibility of preemption]. Voprosy Ekonomiki, 1, 107-118.

Pacelli, L., Devicienti, F., Maida, A., Morini, M., Poggi, A., \& Vesan, P. (2008). Employment security and employability: A contribution to the flexicurity debate. Luxembourg: Office for Official Publications of the European Communities.

Panizzon, M., Zürcher, G., \& Fornalé, E. (Eds). (2015). The Palgrave Handbook of International Labour Migration. Basingstoke: Palgrave Macmillan.

Peshkova, V. M. (2016). Transnational Aspects of the Household Economics of Labor Migrants from Central Asia in Russia. Monitoring of Public Opinion: Economic and Social Changes, 1(131), 240-255.

Piore, M. J. (1980). Birds of Passage: Migrant Labour and Industrial Societies. New York: Cambridge University Press.

Rogaly, B. (2009). Spaces of Work and Everyday Life: Labour Geographies and the Agency of Unorganised Temporary Migrant Workers. Geography Compass, 3(6), 1975-1987. https://doi.org/10.1111/j.1749-8198.2009.00290.x

Ryazantsev, S. V. (2016a). Rol' trudovoj migracii v razvitie ehkonomiki Rossijskoj Federacii [The role of labour migration in the development of the Russian Federation economy]. Available on the Internet: http://www.unescap.org/sites/default/files/1\%20Role\%20of\%20Labour\%20Rus\%20report\%20v3-1-E.pdf

Ryazantsev, S. V. (2016b). Contribution of Labour Migration to the Economy of Russia: Evaluation Methods and Results. Gumanitarnye nauki. Vestnik finansovogo universiteta [Humanities and social sciences. Bulletin of the Financial university], 2(22), 16-28.

Sassen, S. 1988. The Mobility of Labor and Capital: A Study in International Investment and Labor Flow. New York: Cambridge University Press.

Schovánková, S. (2013). Determinants of the Spatial Distribution of Foreign Employees on Different Skill Job Positions: The Case of the Czech Republic. Danube, 4(2), 115-139. https://doi.org/10.2478/danb-2013-0006

Shchipanova, D. G. (2013). Today the global labor market. MIR [World] (Modernization. Innovation. Research), 3(15), $26-30$.

Siedel, T. (2007). The impact of globalization with rigid labour markets. Ludwig-Maximilians-Universität München: doctoral thesis. Available on the Internet: https://edoc.ub.uni-muenchen.de/7293/1/Seidel_Tobias.pdf

Sinning. M. G., \& Vorell, M. (2009). The Effect of Ethnic Residential Segregation on Wages of Migrant Workers in Australia. Available on the Internet: https://editorialexpress.com/cgi-bin/conference/download.cgi?db_name=ESAM09\&paper_id=257

Sitarchuk, E. A. (2012). Institucional'noe regulirovanie vneshnih istochnikov razvitiya potenciala trudovyh resursov nacional'noj ehkonomiki [Institutional regulation of external sources of development of the labour potential of the national economy]. YUzhnyj federal'nyj universitet: $\mathrm{PhD}$ thesis. Available on the Internet: http://dlib.rsl.ru/viewer/01005044504\#?page=1

Škuflić, L.; Krpan, M.; Žmuk, B. (2018). Migration and the economic crisis in the European Union member states: cluster analysis. Entrepreneurship and Sustainability Issues, 6(2), 979-1000. https://doi.org/10.9770/jesi.2018.6.2(34)

Solovieva, N. N. (2016). Obespechenie ehffektivnoj zanyatosti trudovyh migrantov na rossijskom rynke truda [Ensuring effective employment of labour migrants in the Russian labor market]. Tomskij gosudarstvennyj universitet: PhD thesis. Available on the Internet: http://search.rsl.ru/ru/record/01008525862 


\section{ENTREPRENEURSHIP AND SUSTAINABILITY ISSUES}

ISSN 2345-0282 (online) http://jssidoi.org/jesi/

2019 Volume 6 Number 3 (March)

http://doi.org/10.9770/jesi.2019.6.3(11)

Sosnina, I. V. (2012). Trudovaya migraciya $v$ zhiznennyh istoriyah [Labor migration in life stories]. Saratovskij gosudarstvennyj tekhnicheskij universitet imeni Gagarina YU.A.: PhD thesis. Available on the Internet: http://search.rsl.ru/ru/record/01005520274

Tatarkin, A. I., Kuklin, A. A., \& Cherepanova, A. V. (2008). Socio-demographic safety of regions of Russia: current condition and problems of diagnostics. Economy of Region, 3, 154-162.

The town-planning code of the Russian Federation of December 29, 2004 No. 190-FZ. (2004). Accepted by the State Duma of the Russian Federation on December 22, 2004; approved by Council of the Russian Federation on December 24, 2004. Available on the Internet: http://cis-legislation.com/document.fwx?rgn=7632

Thomas, W.I., \& Znaniecki, F. (1918). The Polish Peasant in Europe and America. Boston: The Gorham Press.

Tomashevskij, K. L. (2011). Politika sochetaniia gibkosti i zashchity v trudovom prave Belarusi i Rossii: nastoiashchee i budushchee [Flexicurity in the labour law of Belarus and Russia: present and future]. Pravo. Zhurnal Vysshey shkoly ekonomiki [Law. Journal of the Higher School of Economics], 4, 154-161.

Topilin, A., \& Parfenceva, O. (2006). Migraciya i rynok truda v usloviyah krizisa [Migration and labour market in the crisis]. Moscow: Maks Press.

Topilin, A.V. (1975). Territorialnoye pereraspredelenie trudovykh resursov $v$ SSSR [Territorial redistribution of human resources in the USSR]. Moscow: Ekonomika Publ.

Trachtman, J. P. (2009). The International Law of Economic Migration: Toward the Fourth Freedom. Kalamazoo, MI: W.E. Upjohn Institute for Employment Research.

Tret'iakova, L. A. (2014). Features of the labor market in modern conditions. National interests: priorities and security, 10 (9), $26-32$.

Tyuryukanova, E. V. 2007. Rossiya budet sil'nee zaviset' ot truda migrantov [Russia will be more dependent on the labour of migrants]. Otechestvennye zapiski 4(37). Available on the Internet: https://www.hse.ru/pubs/share/direct/document/74499710

United Nations. (1987). Report of the World Commission on Environment and Development: Our Common Future A/42/427. Available on the Internet: http://www.un-documents.net/wced-ocf.htm

Vakulenko, E. S., \& Leukhin, R. S. (2015). Investigation of demand for the foreign workforce in Russian regions using applications for quotas. Applied econometrics, 37(1), 67-86.

Vakulenko, E. S., \& Leukhin, R. S. (2016). Wage Dicrimination against Foreign Workers in Russia. Ekonomicheskaya Politika, 11(1), 121142. https://doi.org/10.18288/1994-5124-2016-1-08

Vasil'eva, A. V. (2015). Evaluation of the effectiveness of international labor-migration regulation in the region. Regional Economics: Theory and Pactice, 38(413), 20-32.

Vendina, O. (2004). Moskva ehtnicheskaya: grozit li gorodu gettoizaciya? [Ethnic Moscow: does the city face ghettoization?]. Demoscope Weekly 177-178. Available on the Internet: http://demoscope.ru/weekly/2004/0177/tema05.php

Vitkovskaya, G., \& Panarin, S. (Eds.). (2000). Migration and Security in Russia. Moscow: Carnegie Moscow Center.

Vorobieva, O. D. (2005). Politika i ehkonomicheskaya ehffektivnost' vneshnej trudovoj migracii [The policy and economic efficiency of external labour migration], in KHejfets, B. A. (Ed.). Ispol'zovanie inostrannoj rabochej sily: problemy i perspektivy [The use of foreign labour: problems and prospects]. Moscow: IIEPS RAS, 12-17.

Waldinger, R., Aldrich, H., \& Ward, R. (2000). Ethnic Entrepreneurs. Entrepreneurship, in Swedberg, R. (Ed.). The Social Science View. Oxford: Oxford University Press, 356-388. 


\section{ENTREPRENEURSHIP AND SUSTAINABILITY ISSUES}

ISSN 2345-0282 (online) http://jssidoi.org/jesi/

2019 Volume 6 Number 3 (March)

http://doi.org/10.9770/jesi.2019.6.3(11)

\section{Aknowledgements}

The research was carried out at the expense of a grant from the Russian Science Foundation (project № 18-17-00112 «Ensuring economic security of Russia's western border regions in the conditions of geopolitical turbulence». The author would like to thank Larisa Emelyanova for insightful comments, ideas and support. All flaws and faults are the sole responsibility of the author.

Short biographical note about the contributors at the end of the article (name, surname, academic title and scientific degree, duties, research interests):

Anna LIALINA has the PhD in Geography. She is the junior research fellow at the Center of the Modeling of the Social and Economic Development of Region, Immanuel Kant Baltic Federal University, Kaliningrad, Russia. Currently, she is a candidate for the degree of candidate of geographical sciences. Research interests: external labor migration, modeling of the consequences of external labor migration, the attitude of the population towards migrants, foreign labor and labor market, migration policy and integration policy of migrants, spatial development of the territory.

ORCID ID: orcid.org/0000-0002-8479-413X

Register for an ORCID ID:

https://orcid.org/register

Copyright (C) 2019 by author(s) and VsI Entrepreneurship and Sustainability Center

This work is licensed under the Creative Commons Attribution International License (CC BY).

http://creativecommons.org/licenses/by/4.0/

cC) (i) Open Access 